\title{
Pengelolaan Kawasan Sungai Code Berbasis Masyarakat
}

\author{
Widodo B. ${ }^{1}$; Ribut Lupiyanto ${ }^{2}$; Donan Wijaya ${ }^{2}$ \\ ${ }^{1}$ Pusat Studi Lingkungan (PSL) UII dan Jurusan Teknik Lingkungan FTSP UII \\ ${ }^{2}$ Pusat Studi Lingkungan (PSL) UII \\ email:widodo_indo@yahoo.com
}

\begin{abstract}
Abstrak
Diantara beberapa sungai yang melintas di Yogyakarta, Sungai Code menjadi pusat perhatian banyak pihak dan memiliki tingkat kemendesakan dalam pengelolaannya. Kawasan Sungai Code memiliki potensi positif berupa letak yang strategis dalam orientasinya dengan lokasi lain, eksotisme lingkungan yang berpotensi bagi pengembangan ekowisata, juga potensi sosial budaya yang menarik. Semakin meningkatnya aktivitas pembangunan ekonomi, perubahan tata guna lahan dan meningkatnya pertumbuhan penduduk mengakibatkan tingginya tekanan kawasan sungai terhadap lingkungan. Pemukiman yang padat telah menghiasi bantaran sungai dan kondisi kualitas airnya pun menunjukkan kecenderungan semakin memburuk. Salah satu prasyarat penting dalam implementasi penataan kawasan yang optimal adalah pelibatan peran seluruh stakeholder (community-based development), mulai dari perencanaan hingga operasionalisasi dan evaluasi. Partisipasi masyarakat lokal menjadi kunci strategis untuk dapat diberdayakan dan disinergiskan dengan komponen lainnya. Komunitas masyarakat lokal banyak terbentuk dan terorganisasi di setiap penggal kawasan sungai. Perguruan tinggi dan instansi pemerintah juga banyak melakukan program di Sungai Code. Permasalahan mendasarnya adalah pihakpihak terkait tersebut belum terkoordinasi secara terpadu dan program penataannya juga belum sistematis. Hasil analisa tulisan ini merekomendasikan agar supaya pelibatan partisipasi masyarakat dilakukan melalui pemberdayaan komunitas lokal. Seluruh komunitas yang ada dapat dikoordinasikan dalam satu lembaga formal yang didukung penuh oleh pemerintah daerah. Dukungan pemerintah daerah berupa fasilitasi program, jaringan, hingga pendanaan. Pihak-pihak lain seperti perguruan tinggi, swasta, LSM, dan lainnya juga dapat berperan dengan turut menguatkan komunitas tersebut dengan program-program pemberdayaan.
\end{abstract}

Kata kunci: Sungai Code, Pemberdayaan Masyarakat, Komunitas Lokal

\section{Latar Belakang}

Sungai sebagai salah satu sumberdaya air mempunyai manfaat dan peran yang penting dalam kehidupan manusia. Di Propinsi Daerah Istimewa Yogyakarta terdapat beberapa sungai besar yaitu: Sungai Oyo, Opak, Gadjahwong, Code, Winongo, Bedog, dan Serang. Diantara beberapa sungai tersebut, Sungai Code menjadi pusat perhatian banyak pihak dan memiliki tingkat kemendesakan dalam pengelolaannya. Hal ini disebabkan Sungai Code melintasi Kota Yogyakarta dan berdekatan dengan beberapa tempat strategis, seperti Malioboro, Tugu, Kraton, dan lainnya. Sungai Code melintas pada kawasan pemukiman yang cukup padat di kiri-kanan sungai serta kondisinya menunjukkan kecenderungan makin memburuk dari tahun ke tahun. Semakin meningkatnya aktivitas pembangunan ekonomi, perubahan tata guna lahan dan meningkatnya pertumbuhan penduduk telah mengakibatkan tingginya tekanan kawasan sungai terhadap lingkungan. 
Hulu Sungai Code berasal dari mata air yang berada di Gunungapi Merapi. Mata air ini dimanfaatkan untuk pengairan persawahan di Sleman dan Bantul serta dipergunakan juga sebagai sumber air minum, MCK, perikanan, dan lainnya. Seiring dengan meningkatnya laju pertumbuhan penduduk kawasan sungai Code pun menjadi sasaran untuk dijadikan daerah permukiman. Akibatnya permasalahan di daerah aliran Sungai Code pun menjadi sangat kompleks. Mulai terjadinya pencemaran air sungai, penyempitan badan sungai, tingginya erosi dan sedimentasi, hingga berujung pada seringnya terjadi banjir di daerah aliran Sungai Code. Hal tersebut disebabkan padatnya permukiman penduduk di sekitar bantaran Sungai Code yang seharusnya tidak dimanfaatkan sebagai tempat tinggal. Bila kondisi ini terus dibiarkan, maka dampak yang akan dirasakan adalah berubahnya fungsi sungai menjadi kawasan yang tidak tertata dengan baik serta munculnya persoalan sosial dan ekonomi di masyarakat.

Konversi lahan di Yogyakarta menjadi daerah terbangun memberi dampak pada air larian yang dapat dilihat melalui analisis koefisien aliran. Data Balai Besar Wilayah Sungai Serayu Opak (2008) menunjukkan nilai koefisien aliran yang lebih tinggi, yaitu (56\%) yang berarti kemampuan lahannya dalam menahan air relatif sangat rendah. Nilai tersebut dari tahun ke tahun terus menunjukkan kecenderungan peningkatan yang berarti bahwa kemampuan lahan untuk mengikat/menyimpan air semakin menurun. Hal ini tentu sangat berpengaruh pada bagian hilirnya. Semakin mendekati perkotaan, kepadatan kawasan Sungai Code juga semakin tinggi. Kemiskinan dan kekumuhan merupakan implikasi negatif dari kondisi tersebut.

Kawasan Sungai Code selain memiliki potensi positif berupa letak yang strategis dalam orientasinya dengan lokasi lain, eksotisme lingkungan yang berpotensi bagi pengembangan ekowisata, juga potensi sosial budaya dan perhatian banyak pihak. Komunitas masyarakat lokal banyak terbentuk dan terorganisasi di setiap penggal kawasan. Perguruan tinggi dan instansi pemerintah juga banyak melakukan program di kawasan Sungai Code. Permasalahan mendasarnya adalah pihak-pihak terkait tersebut belum terkoordinasi secara terpadu dan program penataannya juga belum sistematis.

Yogyakarta dikenal sebagai kota wisata dengan slogan “Yogyakarta Never Ending Asia”. Kondisi Sungai Code yang kurang representatif dalam mendukung pariwisata Yogyakarta menuntut dilakukan upaya penataan secara terpadu dan berkelanjutan. Balai Besar Wilayah Sungai Serayu Opak (2008) mendasarkan Undang-Undang Sumber Daya Air No. 7 Tahun 2004 telah merumuskan strategi pengelolaan dan pengembangan Sungai Code yang ditekankan pada 5 aspek, yaitu: (1). konservasi sumber daya air, (2) pendayagunaan sumber daya air, (3) pengendalian daya rusak air, (4) pemberdayaan dan peningkatan peran masyarakat, swasta dan pemerintah, serta (5) keterbukaan dan ketersediaan data dan informasi sumber daya air. 
Salah satu prasyarat penting menuju implementasi penataan yang optimal mendasarkan uraian di atas adalah pelibatan peran masyarakat (community-based development), mulai dari perencanaan hingga operasionalisasi dan evaluasi. Mendasarkan konsepsi dan kenyataan yang ada, diperlukan penelaahan bagaimana pengelolaan Sungai Code dengan menguatkan peran komunitas lokal.

\section{Konsepsi Pengelolaan Sungai}

\section{Konservasi Lingkungan Sungai}

Konservasi lingkungan sungai dititikberatkan pada pengelolaan daerah aliran sungai baik daerah bantaran maupun lingkungan airnya. Analisis konservasi dapat dilakukan dengan peralihan tata guna lahan dan pengaruhnya terhadap kualitas air dan kualitas udara setempat (Widodo, 2004). Hal ini penting untuk menjawab tingkat kenyamanan dan tingkat kebutuhan penanganan polusi, terutama konsep penghijauan sebagai paru-paru kota yang berperan penting bagi umat manusia.

Konsep analisis konservasi lingkungan dapat dilihat pada Gambar 1.

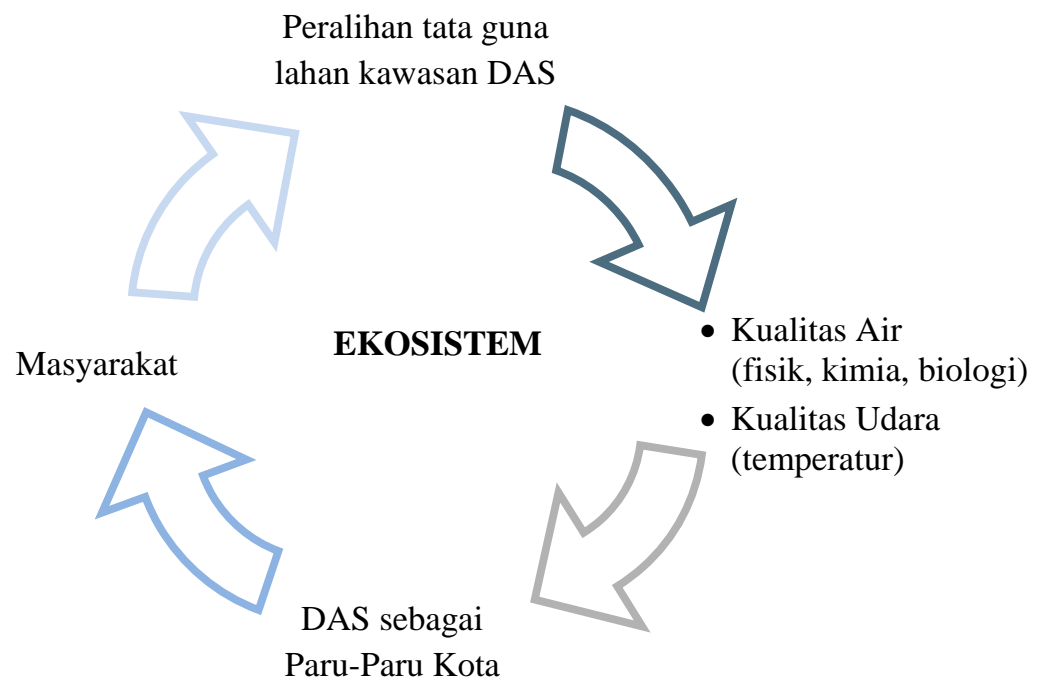

Gambar 1. Konsep Analisis Lingkungan

Analisis tersebut kemudian dapat digunakan sebagai dasar dalam penyusunan konsep konservasi terutama terkait dengan tata kelola daerah sungai.

\section{Pengelolaan Sungai yang Berkelanjutan}

Pengelolaan lingkungan mempunyai ruang lingkup yang luas dengan cara yang bervariasi pula. UU No. 23 tahun 1997 Bab I Pasal 1 ayat (2) menyebutkan bahwa pengelolaan lingkungan hidup merupakan "Upaya terpadu untuk melestarikan fungsi lingkungan hidup yang meliputi 
kebijaksanaan penataan, pengembangan, pemeliharaan, pemulihan, pengawasan, dan pengendalian lingkungan hidup”. Soemarwoto (2001) menunjukkan ada 4 tipe dalam pengelolaan lingkungan, yaitu:

a. Pengelolaan lingkungan secara rutin.

b. Perencanaan dini pengelolaan suatu daerah yang menjadi dasar dan tutunan bagi perencanaan pembangunan.

c. Perencanaan pengelolaan lingkungan berdasarkan perkiraan dampak lingkungan ynag akan terjadi sebagai akibat suatu proyek pembangunan yang sedang direncanakan.

d. Perencanaan pengelolaan lingkungan untuk memperbaiki lingkungan yang mengalami kerusakan, baik karena proses alam maupun tindakan manusia.

Agenda 21 Indonesia yang merupakan penjabaran Agenda 21 Global telah merumuskan strategi nasional dalam program dan strategi pengelolaan lingkungan yang dikelompokkan menjadi empat bidang, yaitu: pelayanan masyarakat, pengelolaan limbah, pengelolaan sumberdaya tanah, dan pengelolaan sumberdaya alam. Keempat agenda tersebut menunjukkan upaya pengelolaan lingkungan yang dilakukan secara komprehensif dan terpadu dengan mengikutsertakan aspek fisik dan sosial ekonomi.

Pengelolaan sungai sebagai bagian pengelolaan lingkungan memiliki tantangan yang sangat mendasar yaitu bagaimana mengelola sumberdaya sungai dan daya dukung lingkungan bagi manfaat manusia secara optimal dan berkelanjutan. Sumberdaya alam dan daya dukung lingkungan dari kawasan sungai harus dikembangkan sedemikian sehingga menguntungkan secara sosialekonomi dan ramah lingkungan. Pengembangan tersebut harus memperhatikan adanya berbagai konflik kepentingan yang mungkin terjadi antar beberapa pihak dengan masyarakat tradisional.

Pengelolaan lingkungan yang berkelanjutan memiliki dimensi ekologi, ekonomi dan sosial (Zulkifli, 2003 dalam Widodo et al, 2009). Dimensi ekologi lebih menekankan pada pentingnya upaya-upaya untuk mencegah terganggunya fungsi dasar ekosistem sungai sehingga tidak akan mengurangi fungsi layanan ekologi. Dimensi ekonomi menekankan bahwa pertumbuhan dan efisiensi dalam pemanfaatan sumberdaya alam harus diupayakan secara terus menerus. Dimensi sosial mencakup isu-isu yang berkaitan dengan distribusi kekayaan/pemerataan secara adil serta penghapusan kemiskinan.

Berdasarkan ulasan Zulkifli (2003 dalam Widodo et al, 2009) beberapa hal yang perlu diperhatikan untuk menjamin keberlanjutan (sustainability) dari pemanfaatan suatu sumberdaya alam, yaitu pemerataan (equity), sociopolytical right, pendidikan, kesehatan dan teknologi. Dalam kondisi 
seperti konsep sustainability mengandung makna keterkaitan dengan konsep daya dukung (carrying capacity) yang dapat dijadikan ukuran tercapainya sustainability dari suatu aktivitas pembangunan. Konsep daya dukung dapat dikelompokkan menjadi dua, yaitu (1) daya dukung biofisik, merupakan ukuran maksimum populasi yang dapat survival di bawah kendali suatu sumberdaya dan teknologi, dan (2) daya dukung sosial, merupakan jumlah penduduk yang dapat hidup layak di bawah kendali suatu sistem sosial.

Upaya pengelolaan sungai perlu menggali, mengkaji dan mepahami sebagai suatu potensi sekaligus hambatan dalam pemanfatannya oleh masyarakat setempat. Pelestarian, pemanfaatan dan pengembangan potensi tersebut harus berpijak pada dukungan ilmu pengetahuan dan teknologi. Ilmu pengetahuan dan teknologi berkembang berdasarkan atas perkembangan kebudayaan manusia masa lalu, kini dan masa mendatang. Tanpa mendasarkan pada ilmu pengetahuan dan teknologi, usaha pengembangan pelestarian dan pemanfaatan sungai cenderung ditentukan oleh pertimbangan sesaat untuk memenuhi kebutuhan yang mendesak. Dengan ilmu pengetahuan dan teknologi, potensi biofisik sungai akan dapat ditingkatkan, dan pelestarian yang efektif dan efisien dapat dikembangkan. Selain pemilihan dan penerapan teknologi tepat guna, dimana teknologi tersebut harus bersifat sederhana, praktis serta berwawasan lingkungan, pengelolaan sungai secara terpadu seharusnya menekankan pada konsep pembangunan berbasis masyarakat (community-based development. Pengelolaan lingkungan mesti didukung penuh dalam dinamika politik lokal. Komitmen politik (political will) terhadap pelestarian lingkungan merupakan kunci menuju pembangunan yang berkelanjutan (Lupiyanto, 2009).

\section{Pemberdayaan dan Partisipasi Masyarakat}

Masyarakat lokal melalui "uji coba“ telah mengembangkan pemahaman terhadap sistem ekologi dimana mereka tinggal (Mitchell, 2003). Hal ini disebabkan telah adanya hubungan yang dekat dengan lingkungan dan sumberdaya alam. Kenyataannya McMulin dan Nielsen (1991) mengungkapkan bahwa pengelolaan lingkungan masih banyak yang berpijak pada konsep pengelolaan profesional yang meyakini golongan profesional yang harus membuat keputusan sedangkan publik kurang mempercayai pertimbangan-pertimbangan mereka. Distribusi kekuasaan dan pengaruh dalam masyarakat merupakan inti dari banyak tantangan lingkungan dan pembangunan, sehingga perlu dipertimbangkan pendekatan baru dalam menyelesaikan masalahmasalah lingkungan, yaitu partisipasi lokal (participatory local appraisal). Pendekatan partisipatori dalam pengelolaan lingkungan perlu mempertimbangkan beberapa hal untuk efektifitas dan optimalisasi usaha, yaitu: alasan, jenis partisipasi dan pelakunya, elemen pendukung, tingkat 
kesertaan, tipe stakeholders yang ada, waktu, komponen program, mekanisme, keadilan sosial, serta monitoring dan evaluasi kerja (Lupiyanto, 2003).

Salah satu pendekatan dalam mewujudkannya adalah penggunaan konsep pembangunan berbasis masyarakat (community-based development). Pembangunan berbasis masyarakat dapat dimaknai sebagai co-management (pengelolaan bersama), yakni pembangunan yang dilakukan oleh masyarakat bersama-sama dengan pemerintah setempat, yang bertujuan untuk melibatkan masyarakat lokal secara aktif dalam kegiatan perencanaan dan pelaksanaan suatu pembangunan dan pengelolaan.

Pengembangan masyarakat (community development) adalah suatu upaya perubahan terencana (planned change) yang dilakukan secara sadar dan sungguh-sungguh melalui usaha bersama masyarakat untuk memperbaiki keragaan sistem kemasyarakatan (Chambers, 2006). Arah perubahan akan sesuai dengan kesepakatan yang telah dirumuskan bersama. Pada intinya instrumen yang digunakan dalam community development adalah pemberdayaan (empowerment). Partisipasi yang tinggi terhadap pembangunan akan menimbulkan rasa ikut memiliki dari masyarakat atas semua sumber daya yang bersifat open acces dan common property di lingkungannya.

Pendekatan ini perlu ditempuh karena masyarakat lokal adalah orang-orang yang paling tahu kondisi sosial budaya setempat. Setiap kegiatan pembangunan harus memperhatikan nilai-nilai sosial budaya pembangunan. Setiap langkah keputusan perencanaan harus mencerminkan keaktifan masyarakat lokal yang ikut terlibat di dalamnya. Pelibatan masyarakat sejak awal akan lebih menjamin kesesuaian program pengembangan dengan aspirasi masyarakat karena adanya rasa memiliki yang kuat. Konsep pendekatan ini dalam jangka panjang akan memungkinkan tingkat kontinuitas yang tinggi. Pengembangan masyarakat lokal perlu didasarkan pada kriteria sebagai berikut (Law and Hartig, JH., 1993; Usman, 2004):

- memajukan tingkat hidup masyarakat sekaligus melestarikan identitas dan budaya lokal

- meningkatkan pendapatan secara ekonomis sekaligus mendistribusikan merata pada penduduk lokal

- berorientasi pada pengembangan usaha berskala kecil dan menengah dengan daya serap tenaga besar dan berorientasi pada teknologi tepat guna

- mengembangkan semangat kompetisi serta koperasi

- memanfaatkan pariwisata seoptimal mungkin sebagai agen penyumbang tradisi budaya dengan dampak seminimal mungkin. 
Tata kelola sungai juga perlu melibatkan berbagai pihak: pemerintah daerah, akademisi dan masyarakat pinggir sungai sebagai pemangku. Dalam konteks Community Development, ada tiga hal yang perlu mendapat penekanan yaitu partisipasi publik, Community education, dan keberlanjutan.

\section{Potret Sungai Code: Potensi dan Permasalahannya}

\section{Kondisi Lingkungan}

Sungai Code merupakan bagian hilir dari Sungai Boyong yang bersumber dari mata air di kaki Gunungapi Merapi Kabupaten Sleman. Luas keseluruhannya adalah sekitar 4.006,25 Ha. Aliran Sungai Code melintasi tiga wilayah kabupaten/kota, yaitu; Kabupaten Sleman, Kota Yogyakarta dan Kabupaten Bantul; yang bermuara di Sungai Opak Kabupaten Bantul. Panjang sungai total \pm $41 \mathrm{~km}$ (jarak rambu dari muara) terbagi menjadi 2 (dua) yaitu: Sungai Code (sebelah hilir) panjang sungai 17 km dan Sungai Boyong (sebelah hulu) panjang sungai 24 km.

Kondisi Sungai Code terus mengalami penurunan baik dari segi kualitas maupun kuantitas airnya. Fenomena perubahan fungsi penggunaan sungai dan lahan di sepanjang daerah aliran Sungai Code telah mengurangi daya dukung lingkungannya. Secara skematik pemahaman persoalan terkait dengan kondisi Sungai Code ditunjukkan pada Gambar 2.

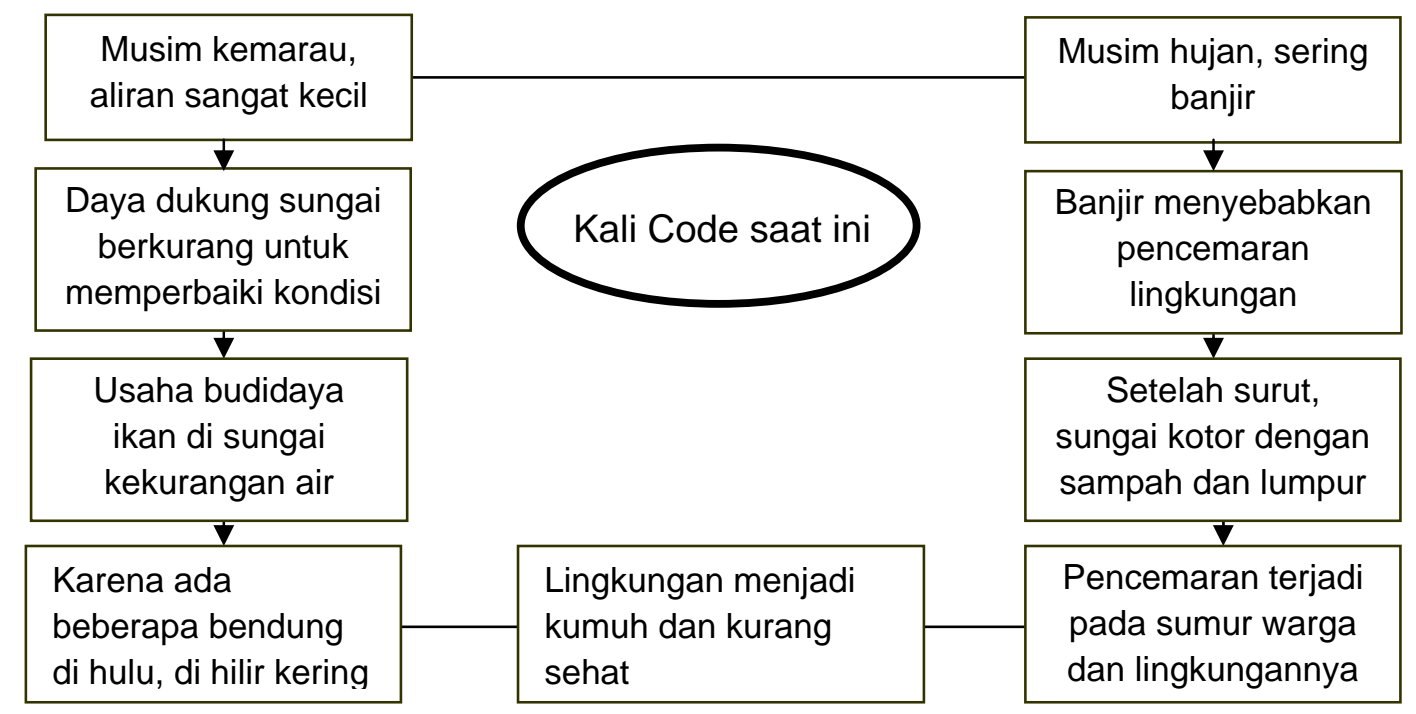

Gambar 2. Komponen Permasalahan Ekosistem Sungai Code

Gambar tersebut menunjukkan betapa vitalnya peran sistem Sungai Code terhadap perkembangan ekosistem di wilayah terkait, terutama untuk menunjang kesejahteraan dan kehidupan warga masyarakat di DAS Code. Arti vital Sungai Code setidaknya dapat dilihat dari beberapa hal nyata yang dijumpai di lapangan sebagai berikut ini: 
a. Sebagai penyangga air tanah daerah di sekitarnya yang digunakan untuk memenuhi kebutuhan air bersih melalui sumur-sumur penduduk/warga Code,

b. Sebagai tempat berternak ikan (di dalam keramba), yang merupakan usaha untuk mendapat tambahan pendapatan keluarga,

c. Sebagai sumber air irigasi sawah (ditunjukkan dengan adanya beberapa bendung),

d. Sebagai saluran drainasi utama kota Yogyakarta,

e. Sebagai badan air yang menampung pembuangan air limbah baik dari limbah rumahtangga maupun dari hotel, rumah sakit, pasar dan lain-lain.

f. Pendukung aktivitas dan keindahan di tengah kota Yogyakarta (di wilayah pusat kota dalam jalur wisata Kraton - Malioboro - Monumen Yogyakarta Kembali), dan menjadi salah satu ciri khas kota Yogyakarta, bahkan pernah terekspose melalui karya Romo Mangun.

\section{Dinamika Kependudukan}

Laju pertumbuhan penduduk di daerah Sungai Code selama kurun waktu 2002-2006 berkisar antara positif 1.75 (Kelurahan Terban) sampai dengan negatif 0.61 (Kelurahan Kotabaru) (Widodo et al, 2009). Pertumbuhan penduduk terutama pada bagian tengah yang merupakan pusat Kota Yogyakarta menunjukkan kecenderungan penurunan (pertumbuhan negatif) sedangkan daerahdaerah yang termasuk wilayah Sleman dan Bantul yang berada di pinggiran Kota Yogyakarta (urban fringe) menunjukkan kecenderungan kenaikan (pertumbuhan positif). Hal ini mengindikasikan adanya perpindahan penduduk dari pusat kota ke daerah pinggiran kota. Namun demikian kepadatan penduduk pada pusat kota masih relatif jauh lebih tinggi dibandingkan dengan kepadatan di wilayah pinggiran kota.

Hal lain yang perlu diperhatikan adalah jumlah penduduk tidak tetap yang pada umumnya merupakan pendatang yang bekerja pada sektor jasa, terutama pada usaha perdagangan. Penduduk dengan mata pencaharian pegawai swasta/negeri cenderung untuk menetap di daerah urban fringe mencari lahan yang relatif masih murah dengan kondisi lingkungan yang masih baik. Sedangkan penduduk yang bergerak di bidang perdagangan dengan sendirinya mencari lahan usaha di tengah kota dengan pertimbangan ekonomis dan menunjang usahanya. Tingginya sektor perdagangan di pusat kota berimbas pada kebutuhan akan tempat tinggal dan sarana publik bagi tenaga kerjanya seperti jasa indekost dan rumah makan. Menjamurnya jasa indekost dan rumah makan di sepanjang sungai Code terutama pada ruas kota perlu mendapat perhatian dan diatur untuk mewujudkan rencana revitalisasi sungai Code. 


\section{Aktivitas dan Ruang Publik}

Sungai Code dahulu memisahkan dua pemerintahan kerajaan, yakni pemerintahan yang dipimpin Sri Sultan Hamengkubuwono dan Pakualam. Oleh karena itu Sungai Code menjadi sangat strategis bukan hanya menjadi batas wilayah politis saja, melainkan merupakan wilayah yang dipadati oleh penduduk yang tinggal di sepanjang sungai.

Seiring perkembangan zaman, penduduk di sepanjang tepian Sungai Code semakin banyak sehingga Sungai Code yang dulu menjadi sumber air untuk memenuhi kebutuhan masyarakat sudah tidak layak lagi karena kondisi air sungai yang sangat memprihatinkan (Bapedalda, 2008; Widodo, 2008). Kampung-kampung di bantaran sungai semakin sesak. Pola nuclear family menyebabkan perkembangan kampung demikian padat dan menghabiskan ruang. Dampaknya warga Sungai Code kehilangan ruang publik, dan satu-satunya tempat yang bisa menjadi pengharapan hanyalah badan sungai, yakni sebagai tempat bermain anak, memancing ikan, hingga tempat berkumpul di malam hari.

Masyarakat yang sudah menetap bertahun-tahun, bahkan konsepsi warisan leluhur membuat masyarakat merasa berkewajiban tetap tinggal di sana. Kebiasaan untuk membuang sampah dan mengalirkan limbah rumah tangga langsung ke sungai telah menurun dari generasi ke generasi. Beberapa perkampungan di sepanjang sungai Code membangun rumah/ bangunan permanen lainnya di bantaran sungai.

\section{Pengembangan Komunitas Lokal Sungai Code}

\section{Evaluasi Partisipasi Komunitas Lokal di Sungai Code}

Banyak pihak memberi perhatian terhadap agenda pengelolaan Sungai Code, baik dari pemerintah, perguruan tinggi, masyarakat maupun kalangan LSM. Pada tahun 2003 tujuh perguruan tinggi di Yogyakarta telah membentuk konsorsium bagi pengelolaan kawasan sungai yang berada di Yogyakarta. Berbagai kelompok masyarakat lokal yang peduli Sungai Code juga telah bermunculan dengan membawa agenda masing-masing, misalnya Gerakan Cinta Code (GCC) di Suryatmajan, Team Komunitas Pinggiran Sungai (TKPS) di Gondolayu, Forum Masyarakat Code Utara (FMCU) dan Masyarakat Peduli Winongo di Badran. Beberapa komunitas telah berkoordinasi dalam Forum Pemerti Kali Code. Permasalahan mendasarnya adalah pihak-pihak terkait tersebut belum terkoordinasi secara terpadu dan program penataannya juga belum sistematis.

Masyarakat selama ini secara kreatif telah berinisiatif melakukan kegiatan, seperti upacara Merti Code, lomba kebersihan lingkungan, pembuatan jalan, juga tamanisasi pinggir sungai. Berbagai 
kegiatan, program, studi, dan aktivitas lainnya menyangkut pengembangan Sungai Code oleh beberapa pihak masih terkesan sporadis dan belum menyentuh sisi manajemen yang berkelanjutan. Berdasarkan aspirasi masyarakat, kebutuhan saluran komunikasi antar warga di bantaran Sungai Code telah disadari tingkat kemendesakannya (Balai Besar Wilayah Sungai Serayu Opak, 2008). Sungai Code adalah sebuah continuum sosial budaya yang tidak dapat dipenggal-penggal secara geomorfologis. Membangun Sungai Code adalah membangun keseluruhan wilayah, mulai dari utara, tengah hingga selatan (Intergrated Regional Development).

\section{Arahan Pengembangan Komunitas Lokal dalam Pengelolaan Sungai Code}

Berdasar pada pola keruangan dan kecenderungan masyarakat yang terbiasa dengan kenyamanan dan komunalitas, maka pemberdayaan harus dilakukan dengan pendekatan yang tepat. Code sebagai kawasan wisata, Code sebagai laboratorium pengolahan air, dan kampung Code yang ditata Romo Mangun dan dilukis oleh para pembuat mural, sudah dilakukan dan memperindah kawasan ini. Kawasan Sungai Code membutuhkan perubahan budaya yang tentunya membutuhkan waktu dan membutuhkan bukti keberhasilan, yakni tercapainya kehidupan yang lebih baik. Posisi pedagang VCD, penjual burjo, atau pun karyawan toko membuat mereka terpatri pada aktivitas hariannya. Jika tidak ada kebutuhan untuk mencapai kehidupan yang lebih baik, maka masyarakat akan berkutat dalam rutinitas dan tidak memikirkan perubahan, karena perubahan berarti merubah tatanan yang terlanjur nyaman. Maka dalam hal ini, yang dibutuhkan adalah perubahan cara pandang, bahwa hidup bukan hanya untuk mendapat uang namun perubahan gaya hidup yang peduli dengan lingkungannya.

Proses perubahan sosial akan lebih efektif jika didorong oleh faktor dari dalam yang sering disebut sebagai immanent change, dimana perubahan dikarenakan oleh ditemukannya berbagai inovasi baru dalam masyarakat itu sendiri. Perubahan semacam ini tidak membutuhkan berbagai macam penyesuaian sosial masyarakat karena berasal dari masyarakat itu sendiri. Sementara itu, perubahan yang dikarenakan oleh berbagai program pembangunan dari luar masyarakat dan dibawa oleh agen pembangunan disebut sebagai direct contact change. Perubahan semacam ini membutuhkan berbagai macam penyesuaian, baik program yang ditawarkan maupun masyarakat penerima program.

Kebudayaan sebagai rangkaian dari semua bentuk produk maupun kegiatan sosial ekonomi dan seni budaya, merupakan sesuatu yang dinamis. Kebudayaan merupakan rekayasa manusia untuk mengubah alam serta lingkungannya karena memenuhi kebutuhan hidupnya. Sementara itu, 
kebutuhan manusia adalah sesuatu yang berkembang tanpa akhir. Karena kebudayaan sesuatu yang dinamis, maka yang menjadi standar dari nilai-nilai budaya yang ada adalah kesepakatan luhur masyarakatnya. Perubahan kawasan sebagai hasil pengelolaan nantinya tentu akan termasuk perubahan nilai-nilai budaya yang ada pada masyarakat di kawasan ini. Perubahan tersebut diharapkan tidak merusak karakter sosial budaya yang ada.

Masyarakat Yogyakarta sangat menyukai simbol dan mencintai budaya. Budaya yang perlu ditanamkan perlu dilakukan secara simultan sejak dini dan didukung oleh keluarga dan contoh/role model. Role model ini bukan hanya dilihat dari tokoh formal, namun juga insan terdidik dari Sungai Code yang tergerak membangun kampungnya. Perubahan ini bisa dimulai dengan mengajak warga untuk melakukan perubahan, bahwa Yogyakarta merupakan salah satu tolok ukur kedewasaan di Indonesia. Sungai Code di Yogyakarta dapat menjadi role model bagi penataan sungai di Indonesia. Padatnya pemukiman di Sungai Code bukan menjadi halangan untuk melakukan perubahan gaya hidup dan etos kerja. Dan itu dimulai dari segala sisi, pemerintah, akademisi, lembaga swadaya masyarakat, dan masyarakat itu sendiri. Pemerintah tentu memiliki kuasa untuk melakukan penataan dan mengeluarkan kebijakan terkait penataan wilayah. Terlebih lagi komunitas dan lembaga sosial yang secara khusus menangangi pendidikan dan kesenian. Upaya ini dapat terus dilakukan bersama sehingga Sungai Code ke depan menjadi percontohan pengelolaan sungai di Indonesia dengan masyarakat sebagai aktor perubahannya. Pancingan dan dukungan dari luar tentu diperlukan untuk mempercepat proses ini.

Saluran komunikasi antar warga dan partisipasi hanya dapat dilakukan dengan proses institusionalisasi (pelembagan). Tujuan utamanya adalah menjaring pendapat dan usulan, melakukan klarifikasi, kategorisasi hingga verifikasi usulan, dan akhirnya melakukan langkahlangkah riil. Integrasi kekuatan dalam sebuah lembaga merupakan salah satu wujud masyarakat modern, dimana tatanan sosial mempunyai payung hukum serta langkah-langkah operasional berdasarkan planning yang jelas dalam menggapai tujuan. Berbeda dengan komunitas yang mempunyai sanksi sosial berdasarkan pranata tanpa tujuan "keuntungan” yang jelas. Sifat dari komunitas adalah komunal dengan mengandalkan pemimpin yang kharismatik, namun sering melupakan kapasitas intelektul. Hal ini yang diharapkan berkembang dengan terwujudnya lembaga untuk masyarakat Sungai Code.

Integrasi kekuatan di Sungai Code adalah modal sosial masyarakat Code untuk mengatur diri mereka sendiri, untuk mewujudkan wilayah sungai yang khas Yogyakarta. Wilayah sungai Code akan menjadi wilayah self design yang dapat di rekayasa masyarakat setempat sesuai budaya relasi manusia dengan Sungai Code itu sendiri. 
Komunikasi yang terbangun melalui lembaga nantinya diharapkan dapat menjadi social relationship menuju harapan-harapan seluruh warga Code atas perbaikan kehidupan yang berbasis pada lingkungan sungai. Oleh karena itu yang terpenting dari lembaga tersebut adalah pola komunikasi. Pola komunikasi inilah yang akan disepakati dengan terbentuknya lembaga masyarakat yang menaungi keseluruhan warga masyarakat yang ada dibantaran Sungai Code, apakah utara, tengah maupun selatan. Sebagai embrio telah terbentuk lembaga Forum Pemerti Kali Code, meskipun prinsip keterwakilan dan kelangkapannya masih belum memenuhi.

Kelembagaan yang ada nantinya harus benar-benar disepakati, mewakili kepentingan masyarakat, dan bersifat semi otonom. Kesepakatan dapat dilakukan dengan proses penjaringan aspirasi serta kordinasi antar komunitas yang ada, seperti unsut lembaga pemerhati, unsur pemerintahan, dan komunitas sosial budaya lainnya. Pelembagaan ini haruslah didukung oleh pemerintah daerah, oleh karena itu pembentukan lembaga disahkan dengan Surat Keputusan Walikota atau sejenisnya. Keberadaan AD/ART dan akte notaris juga mutlak diperlukan pada tahap berikutnya untuk memenuhi kelengkapan lembaga formal. Bagaimanapun proses pengorganisasian masyarakat, apalagi dalam skala cukup besar rentan terhadap potensi konflik sosial. Proses ini haruslah benarbenar berorientasi pada keterlibatan penuh masyarakat secara sistematis dan simultan.

Pengembangan komunitas lokal selain dipengaruhi kebutuhan dan aspirasi/kehendak publik lokal, juga tergantung oleh kebijakan publik pada herarki birokrasi lebih atas. Proses penguatan komunitas lokal dengan demikian tidak lepas dari kemauan politis pemerintah. Oleh karena itu, pemerintah dan legislatif harus benar-benar 'rela' memberikan keenangan pengelolaan melalui komunitas nantinya. Lembaga yang terbentuk harus menyentuh pada semua elemen (institusi) publik hingga level paling bawah dimana arah pengembangannya diorientasikan pada penguatan partisipasi masyarakat. Lembaga tersebut harus memenuhi keterwakilan pemerintah, swasta, dan unsur lainnya, namun porsi terbesar dan peran strategis tentu harus berada pada komunitas lokal.

Beberapa hal yang diperlukan dalam strategi pengembangan kelembagaan lokal,antara lain yaitu:

- Kesiapan pemerintah dalam pembangunan dan pengendalian, baik dari segi kebijaksanaan, dukungan personalia,anggaran maupun administratif.

- Kesiapan masyarakat setempat.

- Kesiapan pihak-pihak lain (swasta) dalam menghadapi kemungkinan adanya hambatan dan dukungan.

Berkaitan dengan hal tersebut diatas, pilihan strategi sudah seharusnya mempertimbangkan dan menyentuh pada tiga hal tersebut di atas. Dalam hal ini, pengembangan kelembagaan perlu 
dipertegas sebagai upaya untuk mengatur berbagai aspek agar dapat mengantisipasi berbagai hambatan dan benturan yang diperkirakan akan terjadi di masa datang.

\section{Penutup}

Mendasarkan pada uraian di atas, dapat disimpulkan beberapa hal sekaligus sebagai rekomendasi, yaitu:

a. Banyak pihak telah memberi perhatian terhadap agenda pengelolaan Sungai Code, baik dari pemerintah, perguruan tinggi , masyarakat maupun kalangan LSM.

b. Permasalahan mendasar dari kontribusi stakeholder dalam pengelolaan Sungai Code adalah pihak-pihak terkait belum terkoordinasi secara terpadu dan program penataannya juga belum sistematis.

c. Forum Pemerti Kali Code sebagai embrio komunikasi antar komunitas merupakan modal baik dalam penguatan komunitas lokal di Sungai Code.

d. Proses pengorganisasian masyarakat dalam rangka penguatan komunitas lokal Sungai Code rentan terhadap konflik sosial, sehingga harus benar-benar berorientasi pada keterlibatan penuh masyarakat secara sistematis dan simultan.

e. Pelembagaan pengelolaan Sungai Code harus bersifat semi otonom dengan memenuhi keterwakilan pemerintah, swasta, dan unsur lainnya, namun porsi terbesar dan peran strategis tentu harus berada pada komunitas lokal.

f. Pembentukan lembaga pengelola Sungai Code harus didukung pemerintah daerah, baik kebijakan, personalia, administrasi, hingga pendanaan.

g. Lembaga pengelola Sungai Code harus diformalkan dengan Surat Keputusan Walikota atau sejenisnya, memiliki AD/ART, akte notaris, dan kelengkapan lainnya.

\section{Daftar Pustaka}

Sekretariat Negara Republik Indonesia. (1997). Undang-Undang Republik Indonesia No. 23 Tahun 1997 Tentang Pengelolaan Lingkungan Hidup. Jakarta.

Balai Besar Wilayah Sungai Serayu Opak, Departemen Pekerjaan Umum. (2008). Laporan Akhir Penelitian “Revitalisasi Sungai Code dan Anak Sungainya Provinsi DIY”. Yogyakarta.

Bapedalda DIY. (2008). Laporan Akhir Penelitian “Kajian Lingkungan Hidup Strategis Kabupaten Sleman, Kabupaten Bantul, dan Kota Yogyakarta”. Yogyakarta. 
Chambers, Robert. (2006). Participatory Rural Appraisal: Memahami Desa Secara Partisipatif. Penerbit Kanisius. Yogyakarta.

KMNLH. (1996). Srategi 21 Indonesia: Strategi Nasional untuk Pembangunan Berkelanjutan. Jakarta.

Law dan Hartig, J.H. (1993). Public Participation in Great Lakes Remedial Action Plan. Plan Canada. March: 31-5.

Lupiyanto, Ribut. (2003). Partisipatori Demokrasi Pengelolaan Lingkungan Hidup Menuju Pembangunnan Berkelanjutan dan Berkeadilan di Era Otonomi Daerah. Universitas Gadjah Mada. Yogyakarta.

Lupiyanto, Ribut. (2009). Politik Lokal untuk Pemanasan Global. Kolom Opini Anda pada www.detik.com edisi 16 Juni 2009.

McMullin dan Nielsen, L.A. (1991). Resolutuion of Natural Resource Allocation Conflict Through Effective Public Involvement. Policy Studies Journal. 19(3-4): 553-9.

Mitchell, Bruce, dkk. (2003). Pengelolaan Sumberdaya Alam dan Lingkungan. Gadjah Mada University Press. Yogyakarta.

Soemarwoto, Otto. (2001). Ekologi, Lingkungan Hidup, dan Pembangunan. Penerbit Djambatan. Jakarta.

Usman, Sunyoto. (2004). Pembangunan dan Pemberdayaan Masyarakat. Pustaka Pelajar. Yogyakarta.

Widodo B. (2004). Land Resources Development Under Threat: Yogyakarta Region. International Seminar ISTECS Chapter Europe. 24/07/04. Karlsruhe.

Widodo. (2008). Sustainable Water Resources Management with Special Reference to Rainwater Harvesting: Case Study of KartaManTul, Java, Indonesia. Dissertation, Universität Karlsruhe. Germany.

Widodo, Ribut L., dan Donan W. (2009). Urban Kampong Improvement on Global Warming Mitigation Basis (A Case Study of Code River Bank Settlement Area, Yogyakarta), Proceedings of The First International Seminar on Sicience and Technology, Islamic University of Indonesia (UII) - Universiti Kebangsaan Malaysia - Universiti Malaysia Trengganu, Januari 2009. 